\title{
Food from the Courts: The Indian Experience
}

\author{
Harsh Mander
}

\begin{abstract}
It has been conventionally believed that whereas socioeconomic rights are critical for human survival with dignity, these fall within the domain of the executive and not of courts and the law. The recent experience in India's Supreme Court has demonstrated that these rights - and in particular the right to food - can be both mandated and enforced by courts. In a landmark petition demanding a legally enforceable right to food, the court has converted food and social protection programmes into legal rights, expanded and universalised these rights, and created an independent mechanism for the enforcement of these rights.
\end{abstract}

\section{Contextualising the right to food}

Democratic governments the world over guarantee all people who live within their boundaries the most essential and basic of all rights, and this is the right to life. The fundamental right to life is understood to imply that, for instance, if a person is detained by the state, and dies while in its custody, either because of torture or extra-judicial killings, state authorities are criminally liable for the death. The actual realisation of this right, especially by powerless and disenfranchised people, remains of course flawed and often bitterly contested in many countries. But the theory of such state accountability is rarely contested within the framework of liberal democracy.

The right to enough and assured food to live an active and healthy life with dignity is in principle also an essential component of the fundamental right to life, because life itself is impossible without food. Yet state authorities are conventionally not held responsible when a person loses her life because she cannot access sufficient food for her survival in the same way as a person who dies because the state directly takes her life without resort to due process of law. The death of a citizen by starvation is seen as a moral failure of the state, but rarely one that entails direct punishable criminal or even civil liability of public authorities who were charged with the responsibility to ensure that every man, woman and child in their jurisdictions have access to sufficient food for their survival with dignity.

There are admittedly many tangled ethical and political questions involved here. For one, where do the duties of the state start and those of the individual, family and local community end? There are those who believe that the state's reach and consequent responsibilities are and must remain limited: that whereas governments can support and create appropriate conditions and extend some support, the final responsibility is of people themselves, with the assistance of their kinship and community networks, to organise their own food, shelter, social security, education and health care. This view obliterates vast differences of power and resources, of freedoms and capabilities between people. People are not impoverished, hungry, homeless or destitute because of chance, and even less because of their own intrinsic failings. They suffer often profound, unjust, humiliating and even life-threatening deprivations because of the way the political economy is structured.

They may not own any productive assets like land and capital, or even a home. They may be unable to find work, because none is available, or because they belong to the wrong gender, caste, faith, ethnicity or have a disability. They may suffer because governments fail to redistribute land, protect them during conflict, secure spaces for them for housing, or displace them for big

IDS Bulletin Volume 43 Number S1 July 2012 @ 2012 The Author. IDS Bulletin (c) 2012 Institute of Development Studies Published by Blackwell Publishing Ltd, 9600 Garsington Road, Oxford OX4 2DQ, UK and 350 Main Street, Malden, MA 02148, USA 
dams and industry. They may fall prey to ailments which debilitate or stigmatise them, because of unhygienic water and environments, and not having the necessary resources to seek care in a private clinic. They may be unable to afford a private school for their children. The child may be forced to work, by impoverished parents, or because they lack adult protection and are growing up on the streets without care. An old person may be unable to labour but has no access to food unless she works. It is only the state that has the resources and legitimacy to guarantee each of these persons who live with want, stigma and oppression a full human life of dignity, and the nutrition, shelter, health care, education and social security which are essential to sustain life.

In these debates, there is often also a subtext of different values assigned to different human lives. People are tacitly valued in proportion to what and how much they 'contribute' to society, or in other words to what they can 'produce'. The state is seen to be responsible primarily to protect and facilitate such productive individuals, and these duties are self-limiting because such persons are capable of taking care of most of their essential life-enabling needs. On the other hand, the people who are not productive but dependent deserve only such support as is possible for governments to muster. The aid they get is welfare, not a right. This again limits state responsibility towards people who are paradoxically most in need of support and protection for their survival. The ethical flaw here is to value people on the basis of what they can 'produce' in terms of priced goods and services in the formal market. This disregards many un-priced non-valorised contributions that such persons may make to the world around them; that they are not responsible for their biological limitations such as of disability or age, or social limitations such as of gender; and that many of their failures to 'produce' are not intrinsic but the product of barriers imposed by social norms. A hearing-impaired person has been found to be more accurate in data entry work, and a mentally slow person may be more productive in assembly line factory work which a person with a more agile mind finds boring but the person with a slower mind finds engaging. But most importantly, what needs to be challenged is the premise that human life should be valued for what it can 'produce', rather than for its inherent equal shared humanity. If this ethical principle is accepted, then the state is duty-bound to provide for people in proportion to what they need rather than what they 'produce'.

Courts and constitutions have held back from making socioeconomic rights like that to food, shelter and health care legally binding, because of the finite availability of fiscal resources. It is believed that decisions regarding the amount of tax that should be imposed, on who these burdens should fall and how these resources are to be invested, are all legitimately political decisions of the executive, in which the law and courts should take care not to tread. Therefore even when social and economic rights are acknowledged by courts and constitutions, it is mostly with the caveat that rights involving substantial state expenditure such as for food and housing should be realised only to the extent that it is considered fiscally feasible by the elected government of the day to raise resources for these. However, while public resources are certainly finite and limited, states need to be constrained to raise sufficient resources and to prioritise its expenditure to ensure the survival of all of its people with dignity, and this can be ensured only with the intervention of the law and courts.

A legally enforceable regime of socioeconomic rights must lay a floor of human existence and dignity below which no person can be permitted to slip. It establishes the scaffolding for humane governance, which sets limits to the enormous avoidable human suffering entailed by want of food, a roof to protect one from the extremes of climate, and health care when one is afflicted. It demands state officials to be accountable both for what they do and not do for the most vulnerable and defenceless in society. It affirms that no human being is dispensable, regardless of age and wealth, gender and ability, and what they are deemed to produce and contribute to society.

\section{The right to food and India's Supreme Court}

The unique experience in India since 2001 demonstrates the practical ways in which a right as fundamental as the right to food can become legally enforceable, and have extraordinary impacts on the massive redeployment of state expenditures in favour of the dispossessed, and the coverage with state-supported food supply to millions of children and women and men who live routinely deprived of adequate and assured 
nutrition. It illustrates how a combination of civic and judicial activism has helped elaborate an important socioeconomic right, and progressively made segments of it judiciable. This experience of Indian courts and civic action in enforcing the right to food is useful also to illuminate the vexed and as yet unresolved debate about the justiciability of socioeconomic human rights like the right to food, or in simple terms whether a person who is denied this right can go to court both to get the right enforced and to ensure punishment to those in authority who denied her this right.

\subsection{India's Constitutional provisions for the right to food: history and development}

When the Indian Constitution - a luminous and exceptionally progressive document - was written in the late 1940s, it accepted the prevailing received wisdom of those times, that civil and political freedoms alone, like protections against illegal detention and freedoms of expression and association, can be enforced through courts. It listed these in a chapter on Fundamental Rights. ${ }^{1}$ It reserved another chapter for social and economic rights, which it called Directive Principles of State Policy, ${ }^{2}$ which were morally rather than legally binding. In a literal sense, it is only in this chapter that we find mention of rights such as to food and shelter. The most explicit reference to the right to food can be found in the first part of Article 47 of this chapter of the Indian Constitution. Article $47^{3}$ (Duty of the State to raise the level of nutrition and the standard of living and to improve public health) directs that

The State shall regard the raising of the level of nutrition and the standard of living of its people and the improvement of public health as among its primary duties and, in particular, the State shall endeavour to bring about prohibition of the consumption except for medicinal purpose of intoxicating drinks and of drugs which are injurious to health.

However, the highest courts have vastly expanded the frontiers of Fundamental Rights. Article $21^{4}$ entitled 'Protection of life and personal liberty', guarantees that 'No person shall be deprived of his life or personal liberty except according to procedure established by law'. Over the years, a series of judicial interventions and interpretations have held that this right includes several other socioeconomic rights, including the right to food, right to housing, and right to work. Since life is biologically impossible without regular nutrition, the right to food has been widely recognised by implication as a core fundamental right.

Even this judicial acknowledgement of the right to food as a fundamental right did not until recently have practical impact on the actual realisation of this right by girls and boys, women and men who were routinely deprived of adequate and assured food for an active and healthy life. Indeed this was the experience even of countries like South Africa which explicitly included the right to food in their Constitutions. This was, in practice, because a great deal of ambiguity continued to surround the actual justiciability of this right, or whether a person whose right is denied can seek redress from courts.

In the year 2001, a group of activists under the banner of the People's Union for Civil Liberties (PUCL), Rajasthan, filed a case in the Supreme Court ${ }^{5}$ demanding that the right to food should be recognised as a legal right of every person in the country, whether woman or man, girl or boy. The petitioners in this case claimed that the people of India are confronted with an unconscionable situation of rampant hunger and recurring droughts on the one hand, and governments that fail to prevent hunger although they have the means to do so including overflowing warehouses of rotting foodgrains, on the other.

At the time that the petition was filed, none of us who were associated with it had anticipated the colossal scale and impact the case was to have on the lives of millions of indigent Indians living with desperate poverty and hunger. This Writ Petition (Civil) No. $196^{6}$ has become the most significant litigation for socioeconomic rights, and has blazed a trail which is being observed with interest globally. I believe the reason it had the extraordinary influence that this case has had which is possibly historic - was precisely because it was an idea of which the time had come.

The governments of India and various states responded to the Supreme Court with claims that they already were implementing a range of schemes that adequately secured the right to food for all people. These included feeding programmes for infants, school-going children, 
expectant and nursing mothers and adolescent girls; subsidised cereals retailed through a countrywide network of ration shops; pensions for the aged and wage employment to the ablebodied. In reply, the petitioner (Kavita Srivastava of the PUCL, Rajasthan) and the counsel (Colin Gonsalves of the Human Rights Law Network) requisitioned information from a still incipient civil society network which called itself the Right to Food Campaign to establish the grave flaws and gaps in the coverage and implementation of these programmes.

\section{A human rights-based approach to Constitutional interpretation}

The case caught the imagination of people in far corners of the country, and so much paper came in that I recall court hearings in which we carried masses of files into the courtroom in wheelbarrows!

The learned judges of the Supreme Court were convinced by the burgeoning evidence placed before them, and they then took several highly significant steps. The first of these was to direct all governments that they could not withdraw or abridge any of the benefits that were provided by the range of eight food, livelihood and social security schemes that were vital for all people to secure their right to food. In other words, what the court did was to firstly convert food, livelihood and social security schemes which are vital to food security of vulnerable citizens, into entitlements or rights. This order paved the way for an enforceable right to food for the first time, preventing governments from removing or diluting these schemes, under pressures to reduce fiscal burdens.

Next the Supreme Court established its own independent monitoring mechanisms to ensure compliance with the court orders and to track both hunger and the performance of food, livelihood and social security programmes of all governments across the country, through the device of appointing its independent Commissioners. (Initially, the Court appointed S.R. Sankaran and N.C. Saxena as Commissioners. Mr Sankaran subsequently resigned, and since then I have been working with Dr Saxena for the Court.) Apart from the pleadings of the petitioner and replies and reports of the Union of India and several State Governments, the justices of the Supreme Court have relied significantly on a series of Reports submitted by the Commissioners appointed by the
Supreme Court, to assist it in its deliberations in this case. In their Reports, the Commissioners have attempted firstly to monitor the implementation of various interim orders passed by the Supreme Court in the course of the hearings in the case. They have further reviewed and analysed the performance of Central and State Governments in implementing various schemes and programmes related to the food security of the people of India, particularly vulnerable people. They have investigated and reported on complaints and reports of local failures in food programmes, including starvation deaths. And finally, they have, from time to time, made recommendations to both governments and the Supreme Court of India for possible steps that they may consider to defend and promote the food security of the people of India, particularly vulnerable people.

The third category of orders passed by the Court has been to expand the content and modes of implementation of the various schemes which it had converted into entitlements. For instance, again on the advice of its Commissioners, it ruled that school meals should be locally produced, hot and cooked (and not dry snacks or grain which many governments distributed until then), hygienic, nutritious (of a prescribed minimum caloric level) and with varied menus for every day of the week. It also recognised that school meals are an instrument to teach children social equality, therefore it ruled that preference be given to Dalit cooks. In the ICDS (Integrated Child Development Services), it banned contractors from supplying ready-to-eat food to preschool children, and again required hot cooked meals for children, at least for those above the age of three years. This was a blow against centralised procurement and the possibilities of large-scale centralised corruption. The powerful biscuit-manufacturers lobby saw an enormous opportunity for profit in the Court-expanded programme and recruited members of parliament across party lines and an influential cabinet minister to demand that locally produced and monitored hot meals be replaced by the 'empty calories' of biscuits. This proposal was fought by an informal alliance of conscientious public servants, the national media, concerned professionals and the court Commissioners, and although it was a bloodied battle, victory at the time of writing seems to be with Court orders for decentralised hot cooked meals prevailing in the overwhelming best interests of millions of our 
young malnourished children. Likewise the Court and Commissioners recommended higher pensions for the aged, distributed on time every month at the doorsteps of the impoverished elderly.

And finally the Court ordered the universalising of many of these schemes. The Supreme Court not only converted the schemes into enforceable entitlements, it also ordered that every potential beneficiary in the country must be covered by the programme within a defined time frame. This meant the expansion of the programme several times beyond what it was before the intervention of the Court (the scale and coverage of food schemes were expanded many-fold as the direct result of the Court's orders). It is significant that the Supreme Court refused to concern itself with the 'fiscal feasibility' of its orders to universalise various entitlements. It entertained no caveats that its orders depended on the ability of the governments to raise sufficient resources, neither did it leave any escape door open for governments to default in complying with its directions on the plea that they failed to raise adequate resources.

The first such order of the Court was to universalise for all children in state and stateaided schools one hot and nutritious midday school meal. These today benefit 140 million schoolchildren daily, making this the largest school feeding programme in the world. When the executive had to find ways to raise the revenues needed to operationalise the universalised entitlements, and to finance midday meals, it actually imposed initially a special education cess of 2 per cent on all federal taxes for education including school meals. The second order was that every habitation of every village and slum must have a feeding centre to serve every child below six years, and all pregnant and lactating mothers and adolescent girls.

The Court orders to universalise programmes for feeding children have expanded budgetary allocations exponentially. The Court ordered a phased expansion of the ICDS (preschool nutrition) programme from 0.6 at the time of its order to 1.4 million habitations, and the coverage of every eligible child below six years, who constitute potentially 17 per cent of the total population of more than a billion people. As a result, between the 10th and 11th Plans, the percentage increase in allocations for the ICDS is 372 per cent. The expansion in budgetary allocations for school meals rose even more dramatically between the Plans by 713 per cent. In 2002-03, allocations for midday meals totalled a little more than Rs 10,000 million; this rose almost eight-fold to Rs 80,000 million by 2008-09, and this is entirely the outcome of the Court orders that every child in state or state-aided elementary schools must receive hot cooked meals in school.

\section{Conclusion}

In more than a decade of hearings, the Supreme Court has passed a number of significant orders to advance the right to food of specific food-deprived populations. The effectiveness of civil and judicial intervention in securing the people's 'right to food' can be assessed from the range of the interim orders of the court so far. ${ }^{8}$ These orders have improved significantly the food security of literally millions of people living with hunger.

The Commissioners and the petitioners, with the active support of the Court, have constantly pushed the frontiers in order to establish, elaborate and enforce new rights of very vulnerable people. During the exceptionally cold winter of 2009 in Delhi, for instance, a number of homeless people died. The Commissioners wrote to the Supreme Court that people die in the cold not because of low temperature, but because they are homeless and severely malnourished. People exposed to severe cold require many more calories simply to maintain body temperature. The Court accepted this and ordered the Delhi government to immediately enhance the number of night shelters. In two nights, in compliance with the directions of the Court, the Delhi government more than doubled the number of shelters, or in other words it opened more homeless shelters in two nights than it had in 60 years since Independence.

The experience of this case illustrates that although the right to food already existed as a fundamental right implicit in the right to life (as do other rights such as to shelter, health care and social security), for these rights to be actually operationalised, courts in response to civic action had to elaborate the right in terms of a series of specific and explicit entitlements. It was not enough to declare that every citizen enjoys the fundamental right to food. Each category of people has varying food needs, denials and 
vulnerabilities, and the Court has in effect 'explicated' or unpacked the right in relation to each segment of people. For an infant, the right to food translates itself into the entitlement of supplementary nutrition of defined specifications in feeding centres. For a school-going child, the right implies hot cooked school meals at state expense. For pregnant women, it means supplementary nutrition and maternity benefits. For designated poor families, it means $35 \mathrm{~kg}$ of state-subsidised rice or wheat every month. For the able-bodied, it means guarantee of food through wage work. For the aged, it means pensions. The unfinished agenda of the Court, I believe, is to secure the rights of individuals who are excluded from all these schemes as they are currently designed, such as a child who cannot go to school, or of malnourished women who are not mothers, or of migrant workers and their families.

The experience of this litigation in the Supreme Court of India has demonstrated that civic and judicial action can combine to ensure that a right such as the right to food, which is vital for human survival, can be guaranteed from the state, in ways that are sensitive and responsive to the specific needs and denials of various categories of food-insecure women and men, boys and girls. Not just courts and citizen groups, but also law-makers and policy formulators can draw lessons from this about how the law and constitutions can establish a floor of enforceable entitlements, of nutrition, but also shelter, social security, health care and education, below which no one will be allowed to fall. If this is accomplished, it is more realistic to dream that a day can dawn in this globe when for the first time in recorded human history, the enormous suffering and indignity of intense human want is at last banished.

\section{Annex}

While the litigation of a case on the right to food is continuing, interim orders are issued by the Supreme Court. The most significant among these orders are on 'food schemes' which refer explicit food entitlements and/or cash assistance to everyone particularly to the poorest of the poor.

The main features of each scheme are outlined below.

\section{Targeted Public Distribution System} (TPDS) - allows the distribution of foodgrain and other basic commodities at a subsidised price through designated local ration shops known as Fair Price Shops (FPSs). It is viewed as a safety net to ensure availability and accessibility of basic commodities, i.e. wheat, rice, sugar and kerosene, to the poor at affordable prescribed prices through FPSs.

Under the scheme, every household is given a ration card corresponding to a category - below the poverty line (BPL) and above the poverty line (APL) - which entitles them to to $35 \mathrm{~kg}$ of foodgrain a month, at higher cost for APL.

The TPDS is operated hand-in-hand by the Central Government and the State Government. The former is responsible for procurement, storage, transportation and allocation of commodities. The latter is responsible for distributing the commodities to claim-holders through FPSs and also undertakes the identification of BPL households vis-à-vis the issuance of ration cards and supervision, including monitoring the FPSs.

The quota for the distribution of commodities for each state is determined by the Planning Commission in reference to the National Sample Survey Organisation's (NSSO) Consumption Expenditure Surveys (CES).

\section{TPDS Court Order Summary}

1 Both BPL and APL are entitled to $35 \mathrm{~kg}$ of foodgrain at a subsidised price.

2 A fixed address is not a requirement to get a ration card. Homeless people are entitled to ration cards.

3 Corruption committed under the Public Distribution System is commensurate with a criminal case under the Essential Commodities Act.

4 An eligible person denied the BPL-TPDS card can apply to an Appellate Authority in a district within 30 days of the incident. The authority concerned shall reach a decision within 60 days. While the appeal is pending, the aggrieved person shall be issued a temporary BPL-TPDS card.

5 The monthly ration shall be made available in instalments.

6 It is the legal duty of all FPS owners to:

- keep their shops open regularly

- charge only the prescribed price

- give the BPL cards to cardholders and not keep them at the FPS

- not make false entries on the BPL cards 
- not store or sell the foodgrain on the open market

- not hand over an FPS to other person/ organisation.

7 The licence of a shop-owner who does not comply with the above provisions shall be cancelled.

- Antyodaya Anna Yojana (AAY) - aims to provide special food assistance through a ration card to destitute households. Cardholders are entitled to $35 \mathrm{~kg}$ of foodgrain a month at Rs $2 / \mathrm{kg}$ for wheat and $\mathrm{Rs} 3 / \mathrm{kg}$ for rice.

Identified destitute households and individuals under a particular social group are provided with an Antyodaya ration card to enable them to receive a foodgrain quota at a subsidised price. Each household is entitled to $35 \mathrm{~kg}$ of wheat or rice, or a combination of the two, every month. The foodgrain is pegged for $\mathrm{Rs} 2 / \mathrm{kg}$ for wheat and Rs $3 / \mathrm{kg}$ for rice. An FPS dispenses the foodgrain quota and cannot charge cardholders more than the pegged price.

\section{AAY Court Order Summmary}

1 Every destitute household or individual in the following social groups is entitled to an Antyodaya card: the aged, the infirm, the disabled, destitute men and women, pregnant and lactating mothers; widows and single women with no regular support; older persons (over 60 years old) with no regular support and means of subsistence; households with a disabled adult member of no assured means of subsistence; households with members who, due to old age, lack physical or mental fitness and need care, or for other reasons no adult member is available to engage in gainful employment outside the house; and primitive tribes (SC Order dated 2 May 2003).

2 Belonging to a BPL social category is not a basis for getting an Antyodaya card. A household or an individual under the aforementioned criteria cannot be denied an Antyodaya card if they are mistakenly not included on the BPL list of the village or erroneously denied a BPL-PDS card previously. Denial of an Antyodaya card to anyone in these groups can be made after due investigation to ascertain the economic-social status of the household or individual.

- The Indira Gandhi National Old Age Pension Scheme (IGNOAPS) - provides a pension to senior citizens with no assured means of subsistence. The coverage and the eligibility of the scheme vary from state to state. IGNOAPS covers all members of the BPL population aged 65 and over.

The Central Government gives Rs 200 pension money and urges State Governments to contribute the same amount. However, implementation is not fully observed. Its eligibility conditions vis-à-vis coverage varies from state to state.

According to state guidelines, old age pension beneficiaries shall get the benefit before the seventh day of every month. However, State Governments often divert or delay the distribution of the cash grant released by the Central Government.

\section{IGNOAPS Court Order Summary}

1 State Governments shall complete the identification of persons entitled for a pension under IGNOAPS, and ensure that it is paid regularly (SC Order dated 28 November 2001).

2 Payment of the pension under the scheme shall be made before seventh day of the month (SC Order dated 28 November 2001).

3 The scheme shall not be discontinued without any preceding order from the Supreme Court (SC Order dated 28 November 2001).

4 The IGNOAPS grants paid by the Central Government to the State Governments under 'Additional Central Assistance' shall not be diverted for any other purpose (SC Order dated 27 April 2004).

\section{- National Family Benefit Scheme (NFBS) -} ensures a cash assistance of Rs 10,000 to a BPL family on the death of the primary breadwinner.

NFBS is a component of the National Social Assistance Programme (NSAP). Under the scheme a lump sum of Rs 10,000 for accidental death and Rs 5,000 for a death due to natural causes is released to the family within a month of application. A primary breadwinner is a family member aged 18-65 years whose earnings contribute substantially to the household income.

\section{NFBS Court Order Summary}

1 A lump sum of Rs 10,000 has to be paid within four weeks of a primary breadwinner's death through the local Sarpanch (SC Order dated 28 November 2001). 
2 The benefit under the scheme cannot be withdrawn until another order is given by any State Government or Union Territory (SG Order dated 18 November 2004).

- National Maternity Benefit Scheme (NMBS) - secures maternity benefits to BPL pregnant women. Introduced in 1995 as part of the NSAP, the scheme entitles pregnant women from BPL households Rs 500 cash assistance. This amount is expended to the women $8-12$ weeks prior to delivery for each of their first two births. This financial assistance is deemed to support their nutritional needs during pregnancy.

The NMBS was, however, modified into a new scheme called the Janani Suraksha Yojana (JSY) in 2005. The JSY is aimed at reducing maternal and/or infant mortality through the promotion of institutional deliveries. Under the scheme, irrespective of the number of births, women who have institutional deliveries are entitled to receive an assistance of $\operatorname{Rs}_{s} 1,400$.

The aforementioned orders were recently reviewed and the Supreme Court ordered the benefit provided in NMBS under JSY to be retained.

\section{NMBS Court Order Summary}

1 Prompt implementation of the scheme must be observed.

2 All BPL pregnant women shall be paid Rs 500 under NMBS 8-12 weeks prior to delivery.

\section{- Integrated Child Development Services} (ICDS) - provides supplementary nutrition, health care, and preschool education to children aged six and under through Anganwadi Centres (AWCs). Introduced in 1975 , ICDS is an integrated package of services for children, extending to adolescent girls, and pregnant and lactating mothers. Health care, growth monitoring, immunisation, supplementary nutrition and preschool education are services directed to AWCs.

Under this programme, children aged six and under are entitled to 500 calories and $12-15 \mathrm{~g}$ of protein. Undernourished children are guaranteed regular intakes of 800 calories and 20-25g of protein, while pregnant and lactating women are entitled to 600 calories and 18-20g of protein a day. The said supplementary nutrition shall be distributed in the form of micronutrient fortified food and/or energy-dense food as takehome rations (THR).

The ICDS is sponsored by the Central Government, excluding the cost of supplementary nutrition, 50 per cent of which is supported by State Governments (except in the North Eastern Region where State Governments support 90 per cent). In 2009, allocation per child on supplementary nutrition was raised from Rs 2 to Rs 4 under normal weight category, Rs 2.70 to Rs 6 per child for those under severely underweight category, and Rs 2.30 to Rs 5 for pregnant and lactating women.

\section{ICDS Court Order Summary}

1 Supplementary nutrition shall be provided to every child aged six and under, adolescent girls, and pregnant women and nursing mothers for 300 days in a year (SC Order dated 29 April 2004).

2 The package of services under ICDS including immunisation, health education, preschool education and supplementary nutrition - must be provided to all children aged six and under, adolescent girls, and pregnant women and nursing mothers (SC Order dated 13 December 2006).

3 Efforts must be made to ensure that all Scheduled Caste/Scheduled Tribe (SC/ST) habitations in the country shall, as early as possible, have operational AWCs. Similar efforts shall also be made to ascertain that all urban slums have AWCs (SC Order dated 7 October 2004).

4 All State/Union Territories shall make an earnest effort to ensure that slums are covered by the ICDS programme (SC Order dated 7 October 2004).

5 The Central Government and States/Union Territories shall ensure that all amounts allocated for the supplementary nutrition programme (SNP) are sanctioned in time to prevent disruption of the programme on the ground (SC Order dated 7 October 2004).

6 All State Governments/Union Territories shall make available on their websites full data on ICDS, including the location of operational AWCs, the number of beneficiaries in each category, the funds allocated and used, and other related details (SC Order dated 7 October 2004).

7 Private contractors shall be banned from supplying the supplementary nutrition. 
Instead, local women's self-help groups (SHGs) and Mahila Mandals shall be encouraged to supply the supplementary food distributed in AWCs (SC Order dated 7 October 2004).

8 The BPL status of a family shall not be a criterion for accessing the ICDS (SC Order dated 7 October 2004).

9 Every community, in both rural and urban areas, where there are more than 40 children under the age of six, is entitled to have an AWC (SC Order dated 13 December 2006).

10 Every settlement in rural areas and urban slums must be covered by an AWC (SG Order dated 13 December 2006).

11 Nutrition and feeding norms shall be altered to ensure the following: children between six months and three years of age are to receive 500 calories and $12-15 \mathrm{~g}$ of protein through the SNP; severely malnourished children, 800 calories and 20-25g of protein; and pregnant women and lactating mothers, 600 calories and 18-20g of protein (SC Order dated 22 April 2009).

\section{- National Programme of Nutritional} Support to Primary Education or Mid Day Meal (MDM) Scheme - entitles every child in primary and upper primary levels in all government and government-assisted schools in all parts of the country to a clean, nutritious, hot cooked meal during school days for a minimum of 200 days.

Food schemes are converted by the Supreme Court into 'legal entitlements' in its order dated 28 November 2001. Embedded in this order is a direction to State Governments to fully implement them according to official guidelines.

In drought-affected areas the meal shall be served on summer vacations. It should contain a minimum of 300 calories and $8 \mathrm{~g}$ of protein.

The stipulated allocation for cooking cost per child a day for the MDM Scheme is Rs 2.50 at the primary and Rs 3.75 at the upper primary level. Moreover, the Gentral Government contributes per child a day $100 \mathrm{~g}$ foodgrain at the primary level and $150 \mathrm{~g}$ foodgrain at the upper primary level. This means that the cooking cost for the meal is shared by the Central and State Governments in a proportion of 75/25 per cent. However, the case is different in states in the North Eastern Region where they share the cost in a proportion of $90 / 10$ per cent.

The scheme provides for the appointment of a cook and a helper by a school with 25 enrollees, two with 26-100 students, and an additional one for every 100 students. Each cook vis-à-vis helper is allocated to receive Rs 1,000 a month.

\section{MDM Court Order Summary}

1 The State Governments/Union Territories shall implement the MDM Scheme by providing every child in every government and government-assisted primary school with a prepared midday meal with a minimum content of 300 calories and $8-12 \mathrm{~g}$ of protein each day of school for a minimum of 200 days (SC Order dated 28 November 2001).

2 A midday meal has to be provided to every schoolchild throughout the summer vacation in all drought-affected areas (SC Order dated 20 April 2004).

3 A midday meal has to be free of cost to all schoolchildren under any circumstances (SC Order dated 20 April 2004).

4 Preference shall be given to Dalits, Scheduled Castes and Scheduled Tribes in the appointment of cooks/helpers (SC Order dated 20 April 2004).

5 The Central Government is directed to allot provisions for the construction of kitchen sheds and also to contribute to the cooking costs of the midday meal (SC Order dated 20 April 2004).

6. State Governments are directed to apportion provisions for quality infrastructure; facilities, i.e. drinking water and toilets; monitoring, e.g. regular inspection; and other safeguards to ensure a nutritious meal is provided to children at primary schools (SC Order dated 20 April 2004).

7 The Central Government is directed to allocate funds to meet the conversion costs of foodgrain into cooked midday meals. Provisions also have to be allocated for the construction of kitchen sheds and improvement of infrastructure and other facilities for the delivery of the midday meal. 


\section{Notes}

1 See Constitution of India arts. 14 to 21.

2 See Constitution of India arts. 36 to 51.

3 Constitution of India art. 47.

4 Constitution of India art. 21.

5 People's Union for Civil Liberties v. Union of India \& Others (PUCL), Writ Petition (Civil) No. 196 of 2001 (India).

6 Ibid.

7 The Right to Food Campaign is an informal network of organisations and individuals committed to achieving the right to food in India that has its origins in the PUCL petition submitted to the Supreme Court in April 2001. It has been integral to the implementation and actual deliverance of the rights and entitlements handed down by the Supreme Court. The key contributions of the Campaign to implementation have been focused on mobilising people on the ground to know and demand their rights, and on facilitating collective action around the realisation of the right to food through a wide range of strategies. Beyond pursuing its objectives through the Supreme Court and state high courts, the Campaign interacts directly with government officials and agencies.

8 For a summary of the orders passed by the Supreme Court so far, visit www.supremecourtcommissioners.org/orders. 